\title{
Teologia Bisericii locale în lumina dialogului teologic dintre Biserica Ortodoxă și Biserica Romano-Catolică
}

\section{Ioan-Veniamin GEOLDEȘ}

Abstract: The concept of local Church and its relation to the Universal Church acquired a major importance for theological debates both within churches and in bilateral and multilateral theological dialogues. In this regard, this study aims to analyze local Church theology from the perspective of Orthodox-Catholic theological dialogue. In our approach we will focus fundamentally on the common theological documents adopted in the dialogue, but we will also consider secondary theological literature generated by the adoption of these specific documents. Analysis of the concept of ,local Church”, highlighting the eclesial criteria of the local church, regulation of the local-universal relation in the One Church as well as the centrality of the local church bishop - are only few of the major coordinates of the local church theology reflected in the common theological documents.

Keywords: the local Church, Eucharistic assembly, diocesan, ecclesial communion, theological dialogue, the Munich document. 


\section{Aspecte preliminare}

În studiul de față ne propunem să analizăm teologia Bisericii locale în lumina documentelor teologice adoptate de comisia mixtă pentru dialog dintre Biserica Ortodoxă și Biserica Romano-Catolică. O simplă lectură a documentelor teologice relevă centralitatea temei în cadrul dialogului ortodoxo-catolic. Astfel, documentul de la München ${ }^{1}$ a consacrat două secțiuni majore acestui subiect: secțiunea a II-a care vizează teologia Bisericii locale cu diferitele ei coordonate, urmând ca în a treia secțiune să fie analizată relația sau raportul dintre Biserica locală și Biserica universală. Tema va fi atinsă, tangențial, și în cadrul următoarelor documente teologice comune: Documentul Bari²: Credinţa, tainele şi unitatea Bisericii (Bari, 1987); Documentul Valamo3: Taina Preoţiei în structura sacramentală a

${ }^{1}$ Acest document este disponibil în revistele „Contacts”, LXIV (2012), nr. 240, p. 455-467; ,Irénikon”, LV (1982), nr. 3, p. 350-362; „,Proche-Orient Chrétien”, XXXII (1982), fasc. 3-4, p. 302-311; „Nicolaus”, XI (1983), fasc. 2, p. 408417; În limba română, la Mitropolitul Antonie Plămădeală, în „Mitropolia Ardealului”, XXVII (1982), nr.10-12 p. 695-702 şi la Irimie Marga, În dragoste şi adevăr. Dialogul teologic oficial ortodoxo-catolic, de la Rodos la Balamand, Piteşti - Brasov - Cluj Napoca, Editura Paralela 45, 2000, p. 55-63. Pentru citările din Documentul München vom opta pentru abrevierea DM, urmat de cifra secţiunii şi a paragrafului, utilizând ediţia din revista Irénikon, indicând secţiunea, numărul paragrafului şi pagina.

${ }^{2}$ Documentul de la Bari ne-a fost accesibil în revistele: „Irénikon”, LX (1987), nr. 3, p. 336-349; Proche-Orient Chrétien, XXXVII (1987), nr. 1-2, p. 90101; „La Documentation catholique” LXXXV (1988), 17 janvier, p. 122-126; Irimie Marga, În dragoste şi adevăr..., p. 106-115. Citările din documentul Bari (abreviat DB) vor fi preluate din revista „Irénikon”, indicând secţiunea, paragraful şi pagina.

${ }^{3}$ Documentul Valamo este disponibil în revistele: Irénikon, LXI (1988), nr. 3, p. 347-359; Proche-Orient Chretien, XXXVIII (1988), nr. 3-4, p. 297-307. Irimie Marga, In dragoste şi adevăr..., p. 133-142. Vom folosi abrevierea DVDocumentul Valamo, iar în cazul citărilor ne vom folosi de varianta din revista Irénikon. 
Bisericii, mai ales importanţa succesiunii apostolice pentru sfinţirea şi unitatea poporului lui Dumnezeu" (Valamo, 1988), care plasează taina Preoției în contextul sinaxei euharistice a Bisericii locale; Documentul Ravenna ${ }^{4}$ : Consecinţe ecleziologice şi canonice ale naturii sacramentale a Bisericii. Comuniune eclezială, sinodalitate şi autoritate (Ravenna, 2007). De o considerabilă importanță pentru studiul de față sunt documentele de la München și Ravenna.

Comisia mixtă internațională a acordat o importanță majoră conceptului teologic de Biserică locală. În acest punct se ridică următoarea întrebare: cum putem explica acest demers teologic al comisiei mixte internaționale de a aborda, chiar din primul document teologic adoptat, problematica Bisericii locale? $\mathrm{Cu}$ alte cuvinte, de ce au ales participanții la dialog să revalorifice teologia Bisericii locale? Pentru a răspunde acestor chestiuni, trebuie să avem în vedere faptul că, atât în teologia ortodoxă cât și în cea catolică, anterioară anilor ' 80 , întâlnim eforturi teologice susținute îndreptate spre redescoperirea importanței Bisericii locale. Astfel, în teologia ortodoxă, conceptul de „Biserică locală” a reapărut în peisajul teologic odată cu reafirmarea eclesiologiei euharistice a teologului rus N. Afanasieff ${ }^{5}$.

În ceea ce priveşte teologia romano-catolică, în perioada anterioară Conciliului Vatican II, problematica teologiei Bisericii locale nu a constituit o temă predilectă de cercetare în rândul teologilor catolici ${ }^{6}$. Este îndeobşte cunoscut teologilor faptul că pentru

${ }^{4}$ Pentru textul documentului de la Ravenna, a se vedea: Irénikon, LXXX
(2007), nr. 4, p. 579-597 ; Istina, LIII (2008), nr. 3, p. 283-296; Proche Orient
Chrétien LVIII (2008), nr. 1-2, p. 79-94. Vom utiliza şi în cazul documentului
de faţă abrevierea DR, urmat de numărul secţiunii, al paragrafului şi al paginii
din revista Istina.
${ }^{5}$ „Ecleziologia euharistică, afirma pr. Ion Bria, are meritul de a fi subliniat
valoarea Bisericii locale, care nu trebuie privită ca o entitate separată, ci ca o
parte integrantă şi deplină a celei universale” (Ion Bria, Ecleziologia comuniunii,
în „,Studii Teologice”, XX (1968), nr. 9-10, p. 676).
${ }^{6}$ Teologul catolic E. Lanne recunoştea faptul că ,înainte de Vatican II, teologia 
eclesiologia catolică care a fost de secole întregi, ,hipnotizată înainte de toate de ideea de universalitate a Bisericii şi de catolicitatea sa, în sens extensiv", o schimbare de paradigmă s-a produs după Conciliul Vatican II, când s-a descoperit, ,înalta semnificaţie a realităţii eclesiale a Bisericii dintr-un loc"7. Conciliul Vatican II a reprezentat astfel un moment decisiv în revalorificarea teologiei Bisericii locale ${ }^{8}$.

\section{Biserica locală - adunarea euharistică ,dintr-un loc”}

Înainte de a analiza coordonatele majore ale teologiei Bisericii locale, trebuie să vedem ce înțelege comisia mixtă internaţională prin sintagma „Biserica locală”. Astfel, în documentul de la München, comisia mixtă afirmă că, în lumina Noului Testament, ,Biserica desemnează o realitate locală. Biserica există în istorie ca Biserică

Bisericii locale a fost foarte puţin prezentă în reflecţia teologică a catolicilor" (L'Église locale et l'Église universelle, în „Irénikon”, XLIII (1970), nr. 4, p. 481). Pentru teologia Biserici locale reflectată în documentele oficiale ale Bisericii Catolice, anterioare Conciliului Vatican II, a se vedea contribuția lui Emmanuel Lanne, o.s.b., L'Église locale: sa catholicité et son apostolicité, în „Istina”, XIV (1969), nr. 1, p. 47-53.

${ }^{7}$ Hans-J. Schulz, Église Locale et Église Universelle. Primauté, Collégialité et Synodalité, în „Proche-Orient Chrétien”, XXX (1981), nr. 1-4, p. 3.

${ }^{8}$ Teologul ortodox J. Meyendorff a evidențiat mutația fundamentală operată în eclesiologia catolică după Vatican II, insistând asupra a două coordonate dezvoltate de Conciliul Vatican II, prin care s-a reușit conturarea unor noi și luminoase perspective de apropiere între cele două Biserici. Prima temă are în vedere redescoperirea semnificației Bisericii locale și, a doua, accentuarea unei teologii a conciliarității/sinodalității în eclesiologia romano-catolică. In lumina acestor noi perspective, Meyendorff sublinia că „,se simte că Biserica romanocatolică este pregătită să accepte alte categorii de reflecție eclesiologică, ca de exemplu, conceptul de «Biserici surori»" (J. Meyendorff, Le Régionalisme dans l'Église: structure de communion ou prétexte de séparatisme? Thèmes de discussion avec le catholicisme romain, în „Contacts”, anul XXXIII (1981), nr. 115, p. 193-210, aici 194). 
locală"’. Pentru a întări această idee, documentul amintește faptul că atunci când se are în vedere o regiune, „se vorbește mai degrabă de Biserici, la plural" ${ }^{\prime 0}$. Documentul Ravenna, în abordarea triplei actualizări a sinodalităţii și autorităţii, la nivel local, regional şi universal, plasează Biserica lui Dumnezeu tot într-o situație locală dată, în contextul adunării euharistice: „Biserica lui Dumnezeu există acolo unde există o comunitate adunată în Euharistia prezidată nemijlocit sau prin preoții săi de un episcop hirotonit legitim în succesiunea apostolică, care învață credința primită de la Apostoli și stă în comuniune cu ceilalți episcopi și Bisericile lor". ${ }^{11}$ Altfel spus, Biserica locală se manifestă ca Trup al lui Hristos atunci când ea este în adunarea sau în sinaxa euharistică. Această afirmație teologică nu trebuie înțeleasă într-un mod unilateral. Dimitri Salachas dezvoltă adagiul patristic: , acolo unde există Euharistia, acolo există Biserică”, introducând în ecuație credința cea adevărată sau ortodoxia Bisericii locale, astfel încât adagiul devine: ,acolo unde există Euharistia celebrată în ortodoxie, acolo există Biserica" ${ }^{\prime 2}$. Observăm, în acest punct, faptul că Biserica locală comportă trei aspecte fundamentale: a) caracterul ei geografic local; b) adunarea euharistică săvârșită în credința ortodoxă; b) episcopul sau preotul ca proestos al adunării euharistice.

\section{Biserica locală -deplină/catolică în sinaxa euharistică}

Comisia mixtă internațională a susținut în mai multe rânduri, în cadrul documentelor teologice, faptul că Biserica locală este cu

\footnotetext{
${ }^{9}$ DM II, 1, p. 354.

${ }^{10}$ DM II, 1, p. 354.

${ }^{11}$ DR II, 18, p. 290.

${ }^{12}$ Dimitri Salachas, Introduzione al Documento di Monaco, în „Nicolaus”, XI (1983), fasc. 2, p. 287-326, aici, p. 295.
} 
adevărat Biserica lui Dumnezeu atunci când ea este în ,,adunare”, iar prin adunare trebuie înţeles adunarea euharistică. Documentul München este elocvent în acest sens:

„Totodată este clar că Biserica, cea «care este» într-un anumit loc, se manifestă ca atare atunci când ea este «adunare». Această adunare, ale cărei elemente și cerințe sunt date de Noul Testament, este deplină atunci când ea este sinaxă euharistică. Într-adevăr, când Biserica locală săvârșește Euharistia, evenimentul care a avut loc odată pentru totdeauna se actualizează și se manifestă’’13.

Membrii comisiei mixte au aplicat în acest pasaj principiul eclesiologic, conform căruia Biserica locală se identifică cu comunitatea euharistică, pornind de la ideea că ,unde este Euharistia, acolo se află și Biserica în plenitudinea sa, ca Trup al lui Hristos"14. Observăm pasul important pe care membrii comisiei mixte de dialog teologic 1-au făcut în ceea ce privește statutul Bisericii locale. Ea nu mai este privită ca o parte a Bisericii universale, ci ca o plenitudine sau deplinătate, sau, altfel spus, ca o manifestare ,într-un loc a catolicității Bisericii lui Dumnezeu, una și indivizibilă" ${ }^{15}$.

\section{Rolul central al episcopului în Biserica locală}

Documentele teologice adoptate în cadrul dialogului insistă asupra rolului privilegiat al episcopului în sânul Bisericii locale, prezența și slujirea sa fiind strâns legate de Euharistie. În acest sens, slujirea sau lucrarea principală a episcopului este aceea de a prezida slujba euharistică. În cadrul documentului de la Valamo (1988),

\footnotetext{
${ }^{13}$ DM II, 1, p. 354.

${ }^{14}$ Ioannis Zizioulas, Biserica locală în perspectivă euharistică, în vol. „Ființa eclesială”, trad. Pr. Dr. Aurel Nae, București, Editura Bizantină, 2007, p. 235. ${ }^{15}$ DR 1, 11, p. 288.
} 
membrii comisiei au afirmat cu tărie această idee: ,în prezidarea comunităţii euharistice, rolul episcopului își atinge deplinătatea"16, sau ,întrucât în slujba euharistică Biserica se descoperă în toată deplinătatea, tot aşa în prezidarea euharistiei rolul episcopului și preotului este pus în lumină"'17. Reflecția teologică a documentului de la Valamo este fundamentată pe eclesiologia euharistică a Bisericii locale, iar această Biserică locală este una centrată în episcop, altfel spus în viaţa Bisericii locale episcopul este capul Bisericii, centrul și unitatea ei $^{18}$. Însă, această centrare a Bisericii locale în episcop nu este concepută într-un mod rigid, unilateral, în izolare de ceilalţi slujitori ai Bisericii, ci în comuniune cu ei. „Slujirea episcopului este strâns legată de adunarea euharistică pe care o prezidează. Unitatea euharistică a Bisericii locale implică comuniunea dintre cel care o prezidează și credincioșii cărora le oferă cuvântul mântuirii și darurile euharistice" $"$.

\section{Condițiile eclesialității Bisericii locale}

Pe lângă coordonatele majore ale teologiei Bisericii locale amintite în punctele anterioare, documentele teologice adoptate semnalează mai multe criterii sau condiţii fundamentale care trebuie realizate sau actualizate în Biserica locală pentru a fi cu adevărat o plenitudine, un spațiu al manifestării într-un loc anume a catolicităţii

${ }^{16}$ DV III, 41, p. 355.
${ }^{17}$ DV III, 34, p. 354.

18 „Episcopul se află în centrul Bisericii sale ca slujitor al Duhului pentru a discerne harismele și a veghea ca acestea să se exercite în înțelegere, în vederea binelui tuturor, credincios tradiției apostolice. El se află în slujba iniţiativelor Duhului, pentru ca nimic să nu le împiedice să contribuie la edificarea koinoniei. El este slujitorul unității, slujitorul Domnului Hristos a cărui misiune este de «a-i aduna în unitate pe toți fiii Domnului»»" (DM II, 3, p. 357 ).

${ }^{19}$ DM II, 3, p. 357. 
Bisericii lui $\operatorname{Hristos}^{20}$. Documentul München amintește două condiții. Primul criteriu are în vedere o anumită raportare retrospectivă $a$ Bisericii locale la Biserica primară, în viziunea participanților la dialog, acest aspect presupunând ,,identitatea tainei Bisericii trăită în Biserica locală cu taina Bisericii trăită de Biserica primară" ${ }^{21}$. Acest prim criteriu de eclesialitate îl regăsim şi în opera mitropolitului Ioannis Zizioulas. Teologul grec definește această condiție drept „,coincidența cronologică sau istorică a Bisericii locale cu trecutul și în special cu Biserica primară și apostolică’"22. Această referință istorică la Biserica apostolică, la tradiția apostolică autentică, garantează autenticitatea și deplinătatea credinței Bisericii locale.

Al doilea criteriu de eclesialitate pentru Biserica locală îl constituie recunoaşterea eclesialităţii unei alte Biserici locale. Acest fapt este fundamental pentru viaţa Bisericii locale, întrucât fereşte comunitatea locală de pericolul autonomizării ei, a transformării într-o unitate de sine stătătoare, a închiderii în sine, fără legătură cu celelalte comunităţi creştine. Documentul München explică acest al doilea criteriu, astfel:

„Recunoaşterea reciprocă între această Biserică locală şi celelalte Biserici este astăzi şi ea de o importanţă capitală. Fiecare trebuie să recunoască în ceilalţi, dincolo de particularităţile locale, identitatea tainei Bisericii. Este vorba de recunoaşterea reciprocă a universalităţii ca şi comuniune în integritatea tainei. Această recunoaştere se împlineşte, mai întâi, în plan regional. [...] această comuniune în interiorul unei regiuni trebuie să fie depăşită în comuniunea dintre Bisericile surori”’23.

${ }^{20}$ Job Getcha, L'Église locale: une problématique oecuménique, în „Istina”, LI (2006), nr. 1, p. 54.

${ }^{21}$ DM III, 3, p. 360.

${ }^{22}$ Ioannis Zizioulas, Euharistie, episcop, Biserică: Unitatea Bisericii în dumnezeiasca Euharistie și în episcop, în primele trei secole creștine, trad. de Pr. Dr. Ioan Valentin Istrati și Geanina Chiriac, București, Editura Basilica, 2009, p. 182.

${ }^{23}$ DM III, 3, p. 360. 
Acest concept de „recunoaștere” reciprocă între diferitele Biserici locale a deplinătății/integrității tainei Bisericii are un bogat conținut eclesiologic ${ }^{24}$. Între aceste Biserici locale, fundamentândune pe mărturia Noului Testament, regăsim: comuniunea în credință, în taine, speranță, iubire, în slujire ${ }^{25}$.

Mijloacele concrete de recunoaștere mutuală între diferitele Biserici locale, altfel spus comuniunea acestor Biserici locale într-o anumită regiune, se realizează prin mai multe practici. Documentul de la Ravenna identifică cinci astfel de practici: ,,a) participarea episcopilor scaunelor vecine la hirotonia unui episcop pentru o Biserică locală; b) invitația adresată unui episcop dintr-o altă Biserică de a concelebra la Liturghia (sinaxis) Bisericii locale; c) invitația extinsă credincioșilor altei Biserici locale de a participa la masa euharistică; d) schimbul de scrisori cu ocazia unei hirotonii; e) oferirea de asistență materială" ${ }^{26}$.

Prin coroborarea celor două condiții - raportarea Bisericii locale la Biserica apostolică și recunoașterea reciprocă a eclesialității între diferitele Biserici locale - se ajunge, în chip firesc, la formularea tezei că ,fiecare Biserică locală este în comuniune nu numai cu Bisericile locale vecine, ci cu totalitatea Bisericilor locale, cu cele prezente acum în lume, cu cele care au fost de la început, cu cele care vor fi în viitor și cu Biserica deja în slavă"'27.

În strânsă legătură cu tema recunoașterii reciproce între diferitele Biserici locale, documentele de la Bari și de la Ravenna au scos în relief importanța Simbolului de credință niceo-constantinopolitan. Pentru a

${ }^{24}$ Jean-Marie R. Tillard, L'Église locale. Ecclésiologie de communion et catholicité, Paris, Les Éditions du Cerf, 1995, p. 244-250, aici p. 246.

${ }^{25}$ DM III, 4, p. 361. „Identitatea unei adunări euharistice cu alta provine din aceea că toate săvârșesc în aceeași credință, același memorial, prin hrănirea cu același Trup și participarea la același potir, devenind același și unic Trup al lui Hristos, în care au fost integrate prin același Botez" (DM III, 1, p. 359 ).

${ }^{26}$ DR II, 23, p. 291.

${ }^{27}$ DR II, 32, p. 293. 
exista o adevărată comuniune între Bisericile locale, participanții la dialog întruniți la Bari (1986-1987) au precizat, drept indispensabilă, raportarea acestora la Simbolul de credință niceo-constantinopolitan, ca la o, ,normă necesară comuniunii în Biserica cea una, răspândită în tot pământul și în toate timpurile"28.

\section{Sinodalitatea în sânul Bisericii locale}

Problematica conciliarităţii sau a sinodalității Bisericii a fost dezbătută, pe larg, de teologii celor două Biserici la a X-a sesiune plenară de la Ravenna ${ }^{29}$. Membrii comisiei mixte au luat ca punct de reper în analiza dimensiunii sinodale a vieții Bisericii temeiul ei ultim şi anume, Sfânta Treime, sinodalitatea reflectând „misterul treimic”. Așa cum indică documentul de la Ravenna, termenul de sinodalitate poate fi înţeles și într-un mod mai general ca referindu-se la toți membrii Bisericii, slujitorii hirotoniţi cât și laicii. „În virtutea Botezului, fiecare membru al Trupului lui Hristos își are locul și responsabilitatea proprie în comuniunea euharistică" ${ }^{\prime 30}$. Slujirea sau funcția proprie fiecărui membru al Bisericii locale este pusă în lumină tot în contextul sinaxei euharistice: „,slujirea episcopului este strâns legată de adunarea euharistică pe care o prezidează. Unitatea euharistică a Bisericii locale implică comuniunea dintre cel care o prezidează și credincioșii cărora le oferă cuvântul mântuirii și darurile euharistice" ${ }^{\prime 31}$. Sinodalitatea la nivelul Bisericii locale implică pe toți membrii Bisericii ,într-o ascultare față de episcopul care e și protos-

${ }^{28}$ DB I, 21, p. 342. A se vedea şi Dimitar Arnaudov, L'Ecclesiologie du Document de Ravenne (2007) de la commission internationale de dialogue catholique-orthodoxe, în „Istina”, LIX (2014), nr. 4, p. 339-366, aici p. 349-350. ${ }^{29}$ Mențiuni importante despre dimensiunea sinodală a Bisericii identificăm și în cadrul celorlalte documentele teologice comune (München, Bari, Valamo).

${ }^{30}$ DR I, 5, p. 286.

${ }^{31}$ DM II, 3, p. 357. 
ul și capul Bisericii locale”. Dar această ascultare a credincioșilor față de episcop nu se poate transforma într-o formă de dominaţie. Între episcop și comunitatea încredințată lui există o profundă comuniune. Numai în acest sens, putem înțelege afirmația comisiei mixte referitoare la interdependența și complementaritatea dintre slujitorii hirotoniți și membrii laici ai comunității: „Harismele membrilor comunitătii își au originea în unul Duhul Sfânt și sunt menite spre binele tuturor. Acest fapt aruncă o lumină atât asupra exigențelor cât și a limitelor autorității fiecăruia în Biserică. [...] toate harismele și slujirile din Biserică converg în unitate, sub slujirea episcopului aflat în slujba comuniunii Bisericii locale" ${ }^{\prime 2}$.

\section{Raportul dintre Biserica locală şi Biserica universală}

Vom începe cu întrebarea: cum a înțeles comisia mixtă internațională de dialog teologic raportul dintre Biserica locală și Biserica universală? Documentul de la München reiterează afirmația că „Trupul lui Hristos este unic”, în consecință „nu există decât o singură Biserică a lui Dumnezeu" "33. Se pot ridica următoarele întrebări: Cum se poate concilia multitudinea sinaxelor locale cu existenţa unui singur trup al lui Hristos? Cum pot fi împăcate noţiunile de pluralitate şi unitate în Biserică? Aceste interogaţii îşi găsesc soluţionarea prin recursul, din nou, la modelul trinitar, la „Dumnezeul cel Unul şi Unic” care este „comuniunea a trei Persoane”. Aceasta este primul model teologic de unitate eclesială propus de Documentul München:

„Koinonia nu exclude diversitatea din pluralitate, ci o presupune şi, totodată, vindecă rănile diviziunii trasncendând-o spre unitate [...] Dumnezeu Unul şi unic este comuniunea a trei Persoane, Biserica una şi unică este comuniunea mai multor comunităţi, iar Biserica locală,

\footnotetext{
${ }^{32}$ DR II, 21, p. 290-191.

${ }^{33}$ DM III, 1, p. 359.
} 


\section{Ioan-Veniamin GEOLDEȘ}

comuniunea de persoane. Biserica una şi unică se identifică cu koinonia Bisericilor. Unitate şi multiplicitate apar în acest punct legate în aşa fel că una n-ar putea exista fără alta" ${ }^{34}$.

Insistând asupra unicităţii Bisericii lui Dumnezeu, documentul München propune şi un al doilea model teologic de unitate eclesială, şi anume modelul ,,Trupului unic al lui Hristos” dăruit, prin Euharistie, creștinilor. Deşi vorbim de o multitudine a adunărilor euharistice, acest fapt nu contribuie la împărţirea Trupului lui Hristos, credinciosul în momentul împărtăşirii ,nu primeşte o parte din Hristos, ci pe Hristos în plinătatea Sa". Oferind acest model de unitate eclesială, comisia mixtă oferă încă o modalitate concretă de rezolvare a raportului local -universal:

„De asemenea, Biserica locală care săvârşeşte, în jurul episcopului, Euharistia nu este doar o parte din Trupul lui Hristos. Multitudinea de sinaxe locale nu împarte Biserica ci dimpotrivă manifestă în mod sacramental unitatea. Aşa cum comuniunea Apostolilor era adunată în jurul lui Hristos, tot aşa fiecare adunare euharistică este cu adevărat sfânta Biserică a lui Dumnezeu, Trupul lui Hristos, în comuniune cu prima comunitate a ucenicilor şi cu toate acelea care au oficiat şi oficiază în lume Patimile Domnului’’35.

\section{Bibliografie}

1. Arnaudov, Dimitar, L'Ecclesiologie du Document de Ravenne (2007) de la commission internationale de dialogue catholiqueorthodoxe, în „Istina”, LIX (2014), nr. 4, p. 339-366.

2. Bria, Ion B, Ecleziologia comuniunii, în ,Studii Teologice”, XX

\footnotetext{
${ }^{34}$ DM III, 2, p. 360.

${ }^{35}$ DM III, 1, p. 359.
} 


\section{Teologia Bisericii locale...}

(1968), nr. 9-10, p. 669-681.

3. Comisia mixtă internațională pentru dialogul teologic dintre Biserica Ortodoxă și Biserica Romano-Catolică, Documentele: München, Bari, Valamo, Ravenna, în revistele citate.

4. Getcha, Job, L'Église locale: une problématique oecuménique, în ,Istina”, LI (2006), nr. 1, p. 52-63.

5. Lanne, Emmanuel, o.s.b., L'Église locale: sa catholicité et son apostolicité, în Istina, XIV (1969), nr. 1, p. 46-66.

6. Marga, Irimie, În dragoste şi adevăr. Dialogul teologic oficial ortodoxo-catolic, de la Rodos la Balamand, Piteşti - Brasov Cluj Napoca, Editura Paralela 45, 2000.

7. Meyendorff, J. Le Régionalisme dans l'Église: structure de communion ou prétexte de séparatisme? Thèmes de discussion avec le catholicisme romain, în „Contacts”, anul XXXIII (1981), nr. 115, p. 193-210.

8. Salachas, Dimitri, Introduzione al Documento di Monaco, în „Nicolaus”, XI (1983), fasc. 2, p. 287-326.

9. Tillard, Jean Marie R, L'Église locale. Ecclésiologie de communion et catholicité, Paris, Les Éditions du Cerf, 1995.

10. Zizioulas, Ioannis Biserica locală în perspectivă euharistică, în vol. „Ființa eclesială”, trad. Pr. Dr. Aurel Nae, București, Editura Bizantină, 2007, p. 235-250.

11. Idem, Euharistie, episcop, Biserică: Unitatea Bisericii în dumnezeiasca Euharistie și în episcop, in primele trei secole creștine, trad. de Pr. Dr. Ioan Valentin Istrati și Geanina Chiriac, București, Editura Basilica, 2009. 